\title{
Studies on Hypoxia: XI. Long-Term Effects on the Epiphyseal Plate-A Histomeric and Radioautographic Study
}

\author{
S. S. HAN,* C. S. KOO,† and M. K. KIM† \\ Departments of Oral Biology and Anatomy, and Program in Biology in Aging, \\ The University of Michigan, Ann Arbor, Michigan 48104, USA
}

Rats were exposed to hypoxia for one week. The mean thickness of epiphyseal plates from control rats was 430 micrometers $(\mu \mathrm{m})$ which was reduced to $313 \mu \mathrm{m}$ in hypoxic rats. Radioautographic incorporation of $3 \mathrm{H}-p h e n-$ ylalanine by connective tissue cells in hypoxic rats was reduced up to $38 \%$ in control rats.

Past studies from our laboratory have shown the suppressive effects of short-term hypoxic exposure on the incorporation of radioactive amino acids into connective tissue cells of rat neonates. ${ }^{1-5}$ The synthesis of proteins in fibroblasts, osteoblasts, and chondroblasts, as measured by the incorporation of $3 \mathrm{H}$ amino acids with the use of radioautography, was suppressed significantly after a brief exposure to total anoxia during the immediate neonatal period. With respect to the effect of chronic hypoxia, a number of biochemical and electron microscopic studies have shown a suppression of secretory protein synthesis by parotid and pancreatic cells in adults rats. ${ }^{6-8}$

The present study was initiated to evaluate the effect of the long-term exposure of rats to a hypoxic environment on the functioning of the epiphyseal plate as determined by histometric measurements and ${ }^{3} \mathrm{H}$-amino acid incorporation by different types of connective tissue cells. Comparisons between chondrogenic and osteogenic cells are of interest in light of the existing consensus that

This investigation was supported by USPHS Grant DE033448, National Institutes of Health, Bethesda, Md. Received for publication May 29, 1975.

Accepted for publication November 25, 1975.

* For reprints: S. S. Han, Cell Biology Laboratory, The University of Michigan School of Dentistry, Ann Arbor, Mich 48104.

† Present address: Seoul National University, College of Dentistry, Seoul, Korea: osteogenic cells are generally more dependent on aerobic metabolism when compared with chondrocytes. ${ }^{9}$

\section{Materials and Methods}

A total of 20, male Sprague-Dawley rats weighing approximately $150 \mathrm{gm}$ each were used throughout this experiment. They were maintained on a diet of rat chow and water ad libitum, and were provided with 14 hours of light and ten hours of dark in an airconditioned animal quarter. The control rats were pair-fed with the experimental rats as described previously by Morawa and Han. ${ }^{6}$ At 5 PM on the day preceding death, food was withdrawn from all rats. Sixty minutes before death, each rat was given an intraperitoneal injection of $3 H$-phenylalanine (specific activity, $5 \mathrm{Ci} / \mathrm{mM}$ ) in the amount of $2 \mu \mathrm{Ci} / \mathrm{gm}$ body weight. The rats were killed by a blow to the base of the skull; this was done at 9 AM to minimize the possibility of diurnal rhythmic effects.

The hypoxic condition was produced by use of an environmental chamber described elsewhere by Morawa. ${ }^{10}$ The chamber provided a continuous flow of $12 \%$ oxygen and $88 \%$ nitrogen under a pressure of less than 2 psi at a constant temperature of $20 \pm 1$ C. The control rats were maintained in an identical chamber except that ambient air was constantly circulated in lieu of the oxygen-nitrogen mixture. All experimental rats were subjected to the hypoxic environment for a period of seven days.

The knee joints including the distal ends of the femur and the proximal end of the tibia were then removed. The joints were cleaned of soft tissues and fixed in $10 \%$ neutral buffered Formalin for two days. This

\footnotetext{
a Purina Rat Chow, Ralston-Purina, St. Louis, Mo.
} 


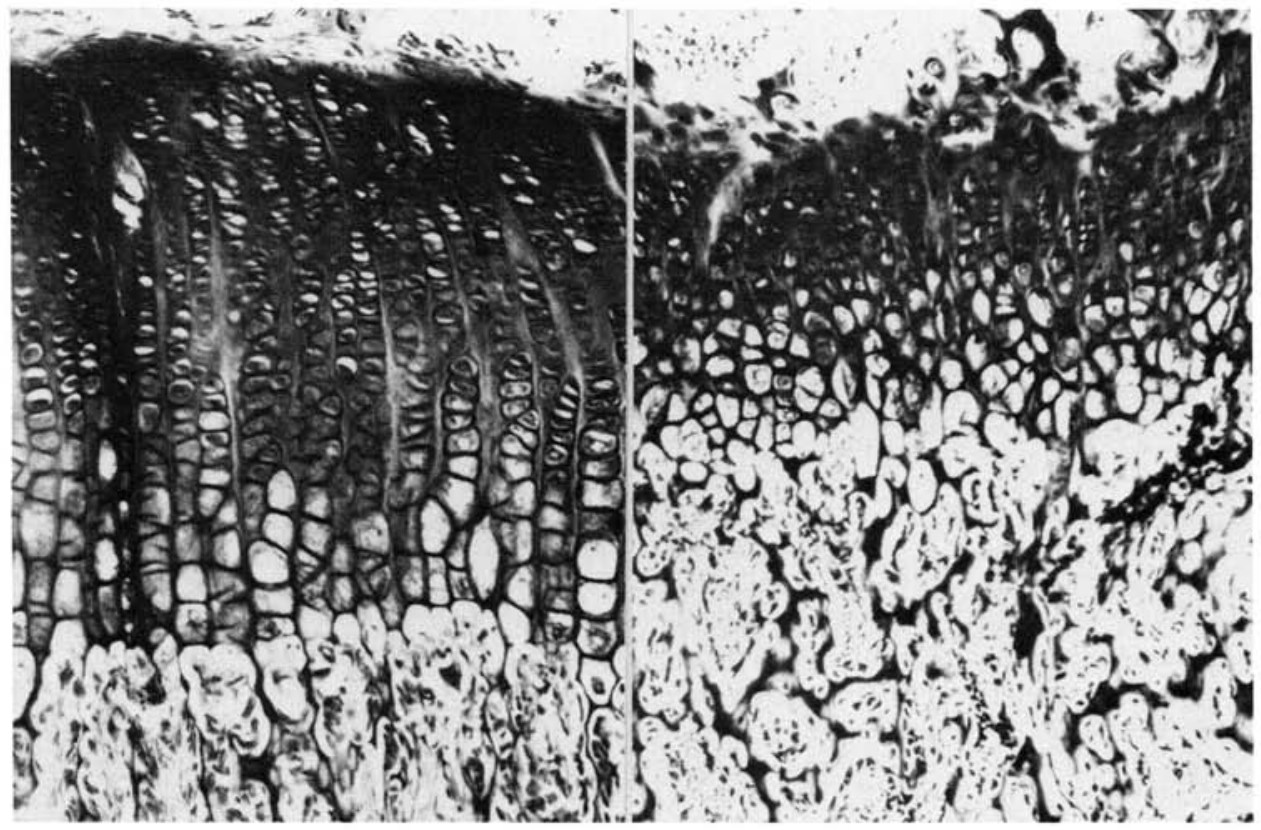

Fic 1.-Macrophotographic comparison of epiphyseal plate thickness of distal femur heads between control and hypoxic rats. Thickness of epiphyseal plate is clearly thicker in control (left) as compared to that from hypoxic rat (right) (enlarged $\times 10)$.
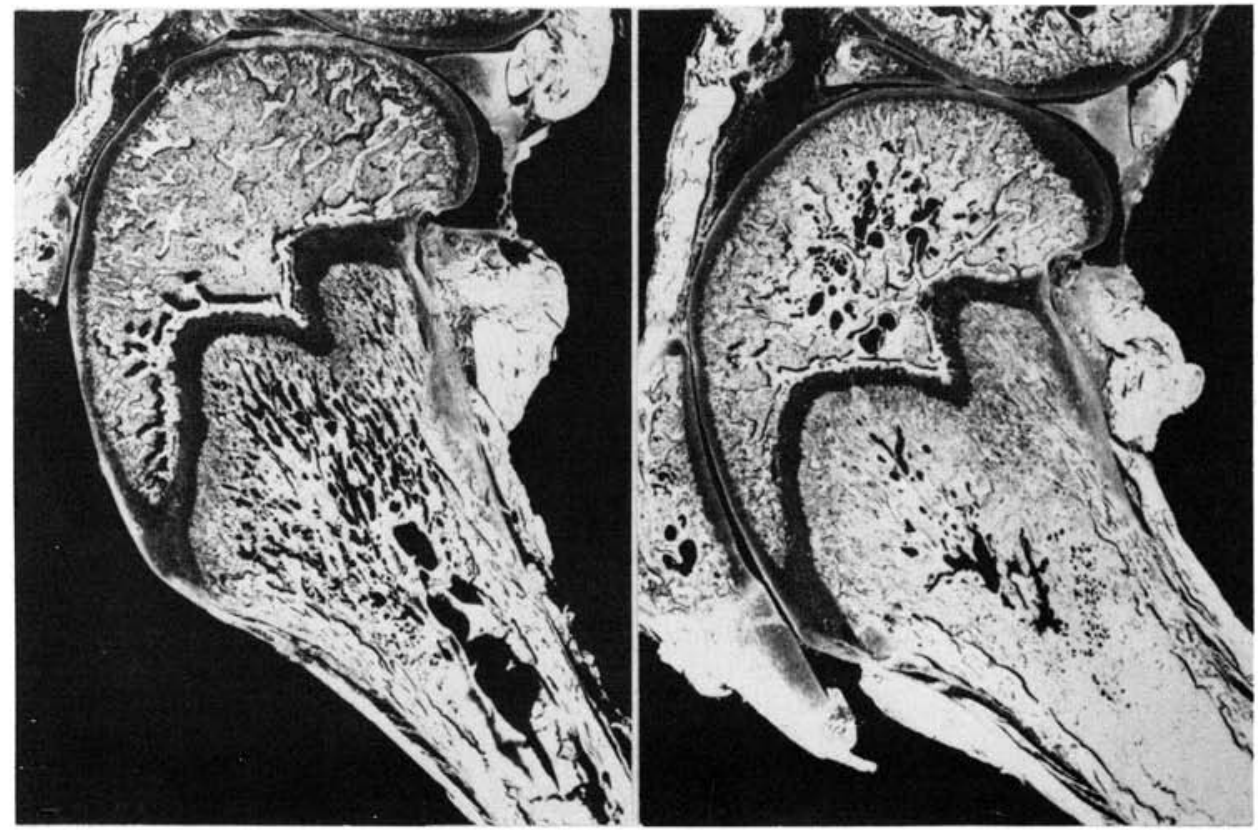

FIG 2.-Histological appearances of epiphyseal plates from control (left) and hypoxic (right) rats. Note well-aligned rows of chondrocytes and osteogenic cells of control. Cells in the experimental femur are generally smaller and more irregularly arranged, presenting distorted and narrowed appearance characteristic to epiphyseal plates seen in cases with growth problems $(\operatorname{mag} \times 212)$. 
was followed by decalcification in $10 \%$ versene for two weeks. Decalcified tissues were double-embedded in parlodion and paraplast in a routine manner. The sections were so oriented that sagittal and parasagittal sections through the Iongitudinal axis of long bones could be made. Sections of 8 micrometer $(\mu \mathrm{m})$ in thickness were made on a rotary microtome and were mounted on $1 \times 3$-inch slides. For radioautography, alternate sections were mounted on different slides and coated with Kodak NTB-3 $^{\mathrm{b}}$ as previously described. ${ }^{2}$ These slides were kept in a refrigerator for four weeks. This allowed adequate development of grain numbers in the respective cell types studied. Radioautographic slides were developed in 2,4-diaminophenol hydrochloride for two minutes in complete darkness and fixed in an ammonium thiosulfate fixer for three minutes. After washing, the slides were stained in Harris' hematoxylin.

The average number of grains over the different cell types was obtained by counting at least 5,000 cells in each sample from the following regions: osteoblasts selected from those that were newly differentiating along the osteogenic zone of the epiphyseal plate; chondroblasts taken from the proliferative zone of the epiphyseal plate; and fibroblasts taken from the periosteal connective tissue in the immediate area of the epiphyseal plate. In addition to radioautographic grain counts made on these cells, the thickness of the epiphyseal plate was measured by using photographs of the sections that were enlarged $\times 10$ (Fig 1). These results were statistically analyzed by calculating the standdard deviation of arithmetic means and evaluating the confidence level using Student's $t$ test on a computerized program.c

\section{Results}

Figure 1 shows representative sections of the distal femur head from control and hypoxic rats taken by photographic enlargement of the sections. It is evident that the thickness of the epiphyseal plate is thicker in the control (Fig 1, left) as compared to that from the hypoxic rat (Fig 1, right). The epiphyseal plate from control rats showed the usual appearance of the histological relationship of developing epiphy-

\footnotetext{
b Kodak rapid fixers, Eastman-Kodak Co., Rochester, NY.

IBM 360/67, IBM Corp., White Plains, NY.
}

seal chondroblasts and osteogenic cells as shown in Figure 2, left, whereas the epiphyseal plate from hypoxic rats showed, when compared to the control, a less clear arrangement of hypertrophic chondroblasts and a more irregular and narrower osteogenic zone.

Table 1 gives the results of measurements made on the thickness of the epiphyseal plates of femurs. Note that the mean thickness of the epiphyseal plates in hypoxic rats was only $312 \mu \mathrm{m}$ as opposed to the $430 \mu \mathrm{m}$ of the control rats. Thus, the mean thickness of the experimental epiphyseal plates amounted to approximately $72 \%$ of the thickness of the control epiphyseal plates.

The result of radioautographic grain counts of different cell types is given in Table 2. It can be noted that, of the control cells studied in this experiment, proliferating chondroblasts have the highest grain counts with a mean number of 41 silver grains per cell, whereas osteoblasts and fibroblasts had mean grain numbers that were only 18 and 11 per cell, respectively. Mean grain numbers in all three cell types from hypoxic rats were reduced significantly from those of the control as given in this table. However, it was of interest that despite the larger mean grain number per control chondroblast, the relative reduction of mean grain number among different cell types in hypoxic rats was the most drastic in fibroblasts that showed 7.6 silver grains per cell in the experimental, or only $66.7 \%$ of the control value. Osteoblasts had 14.8 silver grains per cell in the experimental or $81.7 \%$ of the control value. In contrast to this, the mean grain numbers of chondroblasts of experimental rats were 36.2 per cell which amounted to $87.6 \%$ of the control value.

\section{Discussion}

Results of this study clearly indicate that a prolonged exposure to hypoxia as used

TABLE 1

EFFEct OF Hypoxia ON ThICKNESS OF EPIPHyseal Plate of Rat Femur

\begin{tabular}{lccc}
\hline \hline Treatment & $\begin{array}{c}\text { Mean } \\
( \pm S D)^{*}\end{array}$ & $\boldsymbol{P}$ & $\begin{array}{c}\text { \% of } \\
\text { Control }\end{array}$ \\
\hline Hypoxic & $312.8(46.3)$ & & 72.7 \\
Control & $430.2(76.1)$ & $<0.001$ & 100.0 \\
\hline
\end{tabular}

Note: Values expressed as micrometers.

* Mean of five average measurements from five different rats. 
TABLE 2

Effect of Hypoxia on ${ }^{3} H$-Phenylalanine Incorporation by Chondroblasts, Osteoblasts, and Fibroblasts in Rats: Radioautographic Grain Counts

\begin{tabular}{|c|c|c|c|c|c|c|c|c|c|}
\hline \multirow[b]{2}{*}{ Treatment } & \multicolumn{3}{|c|}{ Chondroblasts } & \multicolumn{3}{|c|}{ Osteoblasts } & \multicolumn{3}{|c|}{ Fibroblasts } \\
\hline & $\begin{array}{c}\text { Mean } \\
( \pm S D)\end{array}$ & $P$ & $\begin{array}{c}\% \text { of } \\
\text { Control }\end{array}$ & $\begin{array}{c}\text { Mean } \\
( \pm S D)\end{array}$ & $P$ & $\begin{array}{c}\% \text { of } \\
\text { Control }\end{array}$ & $\begin{array}{c}\text { Mean } \\
( \pm S D)\end{array}$ & $P$ & $\begin{array}{c}\% \text { of } \\
\text { Control }\end{array}$ \\
\hline Hypoxic & $36.2(45)$ & \multirow[b]{2}{*}{$<0.001$} & 87.6 & $14.8(1.8)$ & \multirow[b]{2}{*}{$<0.001$} & 81.7 & $7.6(0.8)$ & \multirow[b]{2}{*}{$<0.001$} & 66.7 \\
\hline Control & $41.3(4.3)$ & & 100.0 & $18.1(1.9)$ & & 100.0 & $11.4(0.9)$ & & 100.0 \\
\hline
\end{tabular}

Note: Mean counts of at least 500 cells from comparable regions from five different rats.

under these experimental conditions produces serious suppressive effects on the functioning of cells of the epiphyseal plate as evidenced by histometric, histological, and radioautographic analyses of the region. Furthermore, results from a radioautographic study indicate differential effects of hypoxic insult on the three connective tissue cell types present in epiphyseal plates. It is of interest to note that despite a relatively active incorporation of ${ }^{3} \mathrm{H}$-phenylalanine by chondroblasts, the suppressive effect was more serious in cells that had a less active rate of incorporation, namely, fibroblasts and osteoblasts. This is supportive of the possibility that chondroblasts, because of their dependence on anaerobiosis, are capable of more effectively tolerating a reduced oxygen tension, thereby better sustaining their activities than those cells that are more dependent on adequate oxygen support for their synthetic activities.

The relationship between anaerobic glycolysis and the process of tissue calcification has been studied by a number of different investigators. The early work by Guttman and $\mathrm{Yu}^{11-13}$ illustrates well the point in question with respect to the cartilage. They studied whether the calcification in vitro of rachitic epiphyseal cartilage was affected by the addition of inhibitors for specific steps in the sequence of enzymatic reactions of anaerobic glycolysis. It turned out that the calcification was blocked by such inhibitors as phlorizin, iodoacetate, or fluoride if the phosphate donor used was one of the intermediary products of the sequence before the inhibited reaction. In this way, the last of the intermediary products in the sequence that could be identified as being indispensable was found to be phosphoenol pyruvate. However, the importance of mitochondrialinked $\mathrm{Ca}^{2+}$ transport and its intracellular sequestration by osteogenic and other con- nective tissue cells has been repeatedly demonstrated by Talmage, ${ }^{14}$ Mathews, ${ }^{15}$ Lehninger, ${ }^{16}$ and others. Thus, it is now clear that oxidative phosphorylation of adenosin diphosphate is an essential element in the generation of adenosin triphophate in osteogenic cells, as well as $\mathrm{Ca}^{2+}$ capture by mitochondria in which $\mathrm{Ca}^{2+}$ is stored in the form of $\mathrm{Ca}_{3}\left(\mathrm{PO}_{4}\right)_{2}$. A series of histochemical studies of phosphatases and oxidative enzymes by Radden and Fullmer ${ }^{17}$ have also substantiated the fact that several dehydrogenases of the tricarboxylic acid cycle and pentose shunt system are important in osteogenic cell functions.

There is an apparent dichotomy between the results obtained from this study which show a clearcut suppression of overall protein biosynthesis as compared to the increase in protein synthesis observed in the rat parotid gland subjected to similar experimental conditions by Morawa and Han.6 In the parotid gland, the overall cellular protein synthesis was slightly increased in spite of a significant reduction $(45 \%)$ in the amylase content of experimental glands. There is evidence that these results reflect adaptive changes of the cytoplasm that precede the recovery of secretory protein synthesis by cells of the parotid gland.6,10,18 The clear suppression of overall protein synthesis, as can be shown by the reduced ${ }^{3} H$ phenylalanine incorporation by connective tissue cells of the epiphyseal plate, indicates that such an adaptive function, if present in the epiphyseal plate, is not reflected at this time.

However, this conclusion should be taken within the limit of the technical fidelity of quantitative radioautography. In light of the fact that there are few other available means to evaluate the performance of individual cell types in a complicated histological structure such as the epiphyseal plate, 
the result from the present work provides the only experimental evidence that a long-term exposure to hypoxia suppresses amino acid incorporation by connective tissue cells of the growing epiphyseal plate in rats. It suggests further that connective tissue cells of the epiphyseal plate might have a lower rebounding capacity from hypoxic insult, compared to that of the cells of the parotid gland. ${ }^{7}$

\section{References}

1. KIM, J.H., and HAN, S.S.: Studies on Hypoxia: V. Effects of Anoxia on Developing Connective Tissue Cells in Rats, Anat Rec I65: 53 I-542, 1969.

2. Smith, D.M., and Han, S.S.: Studies on Hypoxia: II. Autoradiographic Quantitation of Proline- ${ }^{3} H$ Incorporation by Connective Tissue Cells of the Neonatal Hamster, J Dent Res 47: 244-251, 1968.

3. HAN, S.S.; KIM, J.H.; and Burd, A.R.: Studies on Hypoxia: VII. Effect of Prenatal Anoxia on Leucine ${ }^{3} \mathrm{H}$ Incorporation of Neonatal Rat Pancreas and Submandibular Gland, Proc Exp Biol Med 136: 191-195, 1971.

4. KIM, J.H., and HaN, S.S.: Studies on Hypoxia: III. Effects on Leucine ${ }^{3} H$ Incorporation by Submandibular Gland Cells of Rat Neonates, Proc Soc Exp Biol Med 130: 470473,1968 .

5. PARK, J.H.: Cytologic Effects of Anoxia on Submandibular Glands of Neonatal Mice, $J$ Kore Dent Assn 10:307-316, 1972.

6. Morawa, A.P., and Han, S.S.: Studies on Hypoxia: VIII. Ultrastructural and Biochemical Effects of Prolonged Exposure on Rat Parotid Glands, Exp Mol Pathol 21: 266287, 1974 .

7. KIM, Y.G., and HaN, S.S.: Studies on Hypoxia: IX. Ultrastructural and Biochemical Effects of One-Week Exposure on Rat Pancreas, $A m$ J Anat, in press, 1976.

8. KIM, Y.G., and HaN, S.S.: Studies on Hyp- oxia: X. Effects of Synthetic Polyribonucleotides on Pancreas from Hypoxic and Control Rats: An Electron Microscopic and Biochemical Study, Exp Mol Pathol 23: 4358,1975 .

9. BACHRA, B.N.: Calcification of Connective Tissue, Int Rev Connect Tiss Res 5:165$208,1970$.

10. Morawa, A.P.: An Ultrastructural and Biochemical Study of the Effects of Hypoxia upon Rat Parotid Glands, PhD thesis, University of Michigan, 1973.

11. Guttman, A.B., and YU, T.F.: Further Studies of Relation of Glycogenolysis and Calcification in Cartilage, in ReIfENSTEIN, E.C. (ed) : Metabolic Interrelations, Vol 1, New York: Josiah Macy Jr. Foundation, 1949, pp 11 -26.

12. Gutrman, A.B., and YU, T.F.: A Concept of the Role of Enzymes in Endochondral Calcification, in ReIfenstein, E.C. (ed) : Metabolic Interrelations, Vol 2, New York: Josiah Macy Jr. Foundation, 1950, pp 167-190.

13. Gutrman, A.B., and YU, T.F.: A Further Consideration of Effects of Beryllium Salts on In Vitro Calcification of Cartilage, in REIFENSTEIN, E.G. (ed) : Metabolic Interrelations, Vol 3, New York: Josiah Macy Jr. Foundation, 1951, pp 90-104.

14. Talmage, R.V.: Morphological and Physiological Considerations in a New Concept of Calcium Transport in Bone, $\boldsymbol{A} m \boldsymbol{J}$ Anat 129: $467-476,1970$.

15. Mathews, J.L., and Martin, J.H.: Mitochondrial Granules in Chondrocytes, Calcif Tissue Res 3: 184-193, 1969.

16. LeHNinger, A.L.: Biochemistry: The Molecular Basis of Cell Structure and Function, New York: Worth Publishers, Inc., 1972.

17. Radeen, B.G., and Fullmer, H.M.: Morphological and Histochemical Studies of Bone Repair in the Rat, Arch Oral Biol 14: 1243-1252, 1969.

18. MoraWa, A.P.; KIM, Y.G.; and HaN, S.S.: Unpublished observations, 1975. 